Conclusions: TUS differed between study arms, favouring RTX. This encourages further research into SGUS as an imaging biomarker in PSS clinical trials. Acknowledgements: Funded by Arthritis Research UK. Roche provided RTX. Disclosure of Interest: B. Fisher Paid instructor for: Novartis, Roche, Virtualscopics, C. Everett: None declared, J. Rout: None declared, J. O'Dywer: None declared, P. Emery: None declared, C. Pitzalis: None declared, W.-F. Ng Consultant for: Pfizer, UCB, Medlmmune, Takeda and Sanofi, A. Carr: None declared, C. Pease: None declared, E. Price: None declared, N. Sutcliffe: None declared, J. Makdissi: None declared, N. Gendi: None declared, F. Hall: None declared, S. Ruddock: None declared, C. Fernandez: None declared, C. Hulme: None declared, K. Davies: None declared, C. Edwards: None declared, P. Lanyon: None declared, R. Moots: None declared, E. Roussou: None declared, L. Sharples: None declared, M. Bombardieri Consultant for: GSK, Amgen/Medlmmune and UCB, S. Bowman Consultant for: Cellgene, Glenmark, GSK, Eli Lilly, Novartis, Roche, Takeda, UCB

DOI: 10.1136/annrheumdis-2017-eular.3138

\section{AB0445 HYDROXYCHLOROQUINE'S IMPACT IN RENAL BIOPSY AND OUTCOMES OF LUPUS NEPHRITIS}

D. Navarro, A.C. Ferreira, H. Viana, F. Carvalho, F. Nolasco. Nephrology Department, Hospital Curry Cabral, Lisboa, Portugal

Background: Given its immunomodulatory effects, hydroxychloroquine use is recommended in systemic lupus erythematosus (SLE). It is associated with a lower rate of appearance and of relapse of lupus nephritis (LN). LN is classically classified using ISN/RPS classification, but others indexes, such as the ones described by Austin and Hill, allow for the quantification of SLE activity in the kidney tissue.

Objectives: To analyze the association between the use of hydroxychloroquine and the activity of LN in the kidney biopsy.

Methods: Retrospective single center study of consecutive SLE and biopsy proven LN patients, diagnosed from 2010 to 2016 . We evaluated the following outcomes: clinical remission, renal function and proteinuria at end of followup $(\mathrm{g} / 24 \mathrm{~h})$. Complete remission was defined as a reduction of proteinuria to $<0,5 \mathrm{~g} / 24 \mathrm{~h}$, inactive urinary sediment and serum creatinine $<115 \%$ of baseline; partial remission same parameters, except proteinuria $<1 \mathrm{~g} / 24 \mathrm{~h}$ if initial value $<3 \mathrm{~h} / 24 \mathrm{~h}$, or reduction to $<3 \mathrm{~g} / 24 \mathrm{~h}$ if initial value $>3 \mathrm{~g} / 24 \mathrm{~h}$. Kidney biopsies were evaluated by the INS/RPS LN classification and the morphological indexes described by Austin and Hill, obtained after histomorphological review of renal biopsies. The studied predictor was the use of hydroxychloroquine. Statistical analysis was performed with STATA software, using one-way ANOVA, Qui2 and Pearson/Sperman test were appropriate.

Results: During 6 years, there were 46 biopsy-proven LN cases, $84,8 \%(n=39)$ woman, median 35 years old $(27-42,5)$ and $57,6 \% \quad(n=19)$ caucasian. 39 patients were already known to have SLE, $7,44(1,13-12,3)$ years previously. Of those 39 patients, $46 \%$ were under hydroxychloroquine and $77 \%$ under other immunosuppression.

The median follow-up was $31,9(13,2-45,6)$ months. Based on biopsy findings, 35 patients were started on immunosuppression - induction in $50 \%$ of cases with MMF and in $50 \%$ with cyclophosphamide; maintenance in $81 \%$ with MMF, the rest with azathioprine. Complete remission was achieved in $58 \%$ of patients, $27 \%$ achieving partial remission. We observed $4 \mathrm{LN}$ relapses. At the end of FUP, we saw a $96 \%(n=44)$ patient survival, with a median serum creatinine of $0,8 \mathrm{mg} / \mathrm{dl}$ $(0,7-0,99)$, eGFR $99,8 \mathrm{ml} / \mathrm{min}(71,2-116,8)$ and proteinuria of $0,6 \mathrm{~g} / 24 \mathrm{~h}(0,2-1,6)$. From those 46 patients, 30 were under immunosuppressive therapy at time of LN presentation, and $60 \%(n=18)$ were also under hydroxychloroquine. Table 1 summarizes the clinical findings:

With the use of hydroxychloroquine, we observed a lower histomorphological activity, as represented by a lower Hill biopsy index, and tendency towards lower Activity index. We also saw a tendency towards lower proteinuria.

Conclusions: Our data reinforces the recommendations of using hydroxychloroquine for its adjuvant role in SLE patients, as we saw a lower histomorphological activity in kidney biopsy, and a trend towards lower proteinuria.

Disclosure of Interest: None declared

DOI: 10.1136/annrheumdis-2017-eular.5546

\section{AB0446 ADDITIVE INHIBITION OF INTERFERONS, B AND T CELL ACTIVATION AND TFH-RELATED CYTOKINE CXCL13 BY LEFLUNOMIDE AND HYDROXYCHLOROQUINE SUPPORTS RATIONALE FOR COMBINATION THERAPY IN PSS PATIENTS}

E.H. van der Heijden ${ }^{1,2}$, S.A. Hartgring ${ }^{1,2}$, A.A. Kruize ${ }^{2}$, T.R. Radstake ${ }^{1,2}$, J.A. van Roon ${ }^{1,2}$. ${ }^{1}$ Laboratory of Translational Immunology; ${ }^{2}$ Dept. of Rheumatology \& Clinical Immunology, UMC Utrecht, Utrecht, Netherlands
Background: T and B cell-driven immunity is critically involved in immunopathology of pSS. Recently we demonstrated synergistic T and B-cell activation upon T cell triggering and TLR7/9-driven B cell activation in pSS patients, accompanied by synergistic induction of immunoglobulins and IFN- $\gamma$ - and IL-17-producing T cells ${ }^{1}$. In addition, TLR7/9-expressing activated pDCs associated with increased type I IFNs and IFN-inducible genes are increased pSS patients. Several studies have shown that the DMARDs leflunomide and hydroxycholoroquine inhibit immune activation in pSS but only show moderate efficacy. However, LEF and HCQ target different pathways with overlapping, but also potentially additive mechanisms, where LEF primarily targets $\mathrm{T}$ and $\mathrm{B}$ cells and HCQ TLR7/9-driven B cell and pDC activation.

Objectives: To assess the additive effects of LEF and HCQ on CD4 T- and B-cell activation and production of interferons IFN- $\alpha$ and IFN- $\gamma$, Tfh-related cytokine CXCL13, as well as IgG and IgM in vitro employing SEB/TLR9-triggered PBMC. Methods: PBMCs of healthy individuals $(n=9)$ and of pSS patients $(n=8)$ were cultured with antigen (SEB), TLR9 and their combination, in presence or absence of LEF, HCQ and their combination in clinical relevant concentrations. Proliferation of $T$ and $B$ cells and release of IFN- $\alpha, \operatorname{IFN}-\gamma, C X C L 13, \lg G$ and IgM were measured.

Results: In line with robust $\mathrm{T}$ and $\mathrm{B}$ cell activation, IFN- $\gamma, \mathrm{IFN} \alpha, \mathrm{CXCL} 13, \operatorname{IgG}$ and IgM production was achieved by a combination of SEB and TLR9 (all at least $\mathrm{p}<0.001$ ). LEF dose dependently inhibited $\mathrm{B}$ and $\mathrm{T}$ cell proliferation, Interferon, CXCL13 and immunoglobulin production. HCQ dose dependently inhibited B cell proliferation, IFN- $\alpha, \mathrm{CXCL13}$, and immunoglobulin production. T cell proliferation and IFN- $\gamma$ production were inhibited by $\mathrm{HCQ}$ only at higher concentrations. At several suboptimal concentrations LEF and HCQ additively inhibited T cell proliferation both in healthy individuals and in pSS patients. (Figure 1). Significant additive effects were seen for all outcome measures except IFN- $\alpha$. Since IFNa was already robustly inhibited by $\mathrm{HCQ}$ alone (eg.for pSS $90 \%$ at $3.3 \mu \mathrm{M}, \mathrm{p}<0.001$ ), only trends towards additive effects were observed.

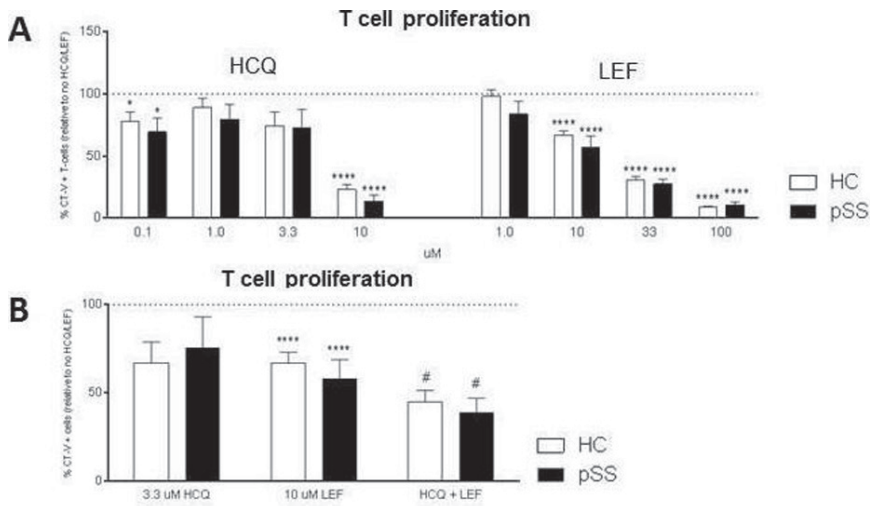

Figure 1. HCQ and LEF additively inhibit T cell activation. T cell proliferation is dose dependently inhibited by LEF and by HCQ at 0.1 and $10 \mu \mathrm{M}$ (A). Significant additive inhibition of $T$ cell proliferation is achieved by combination of suboptimal concentrations of LEF and HCQ both in $\mathrm{HC}$ and pSS patients (B). *and **** indicates statistical significance of $p<0.05$ and $p<0.0001$ resp. vs control, \# indicates statistical significance of $p<0.05$ of the combination vs each of the single drugs.

Conclusions: LEF and $\mathrm{HCQ}$ robustly inhibited proliferation of $\mathrm{T}$ and $\mathrm{B}$ cells, cytokine production and immunoglobulin production with clear additive efficacy in both healthy individuals as in pSS patients. These data support the potential surplus value of combination therapy with LEF and HCQ for patients with pSS. References:

[1] Bikker et al. Interleukin-7 and Toll-Like Receptor 7 induce synergistic B cell and T cell activation. PLoS ONE 9(4): e94756.

Disclosure of Interest: None declared

DOI: 10.1136/annrheumdis-2017-eular.5022

\section{AB0447 ANTIMALARIALS IMPROVE SURVIVAL OF SYSTEMIC LUPUS ERYTHEMATOSUS ON CHOLESTEROL: RESULTS OF A FIFTEEN-YEAR CHINESE MULTICENTER RETROSPECTIVE STUDY IN JIANGSU PROVINCE}

F. Wang ${ }^{1}$, W. Zhang ${ }^{1}$, S. Wang ${ }^{1}$, W. Pan ${ }^{2}$, L. Liu ${ }^{3}$, M. Wu ${ }^{4}$, X. Ding ${ }^{5}$, H. Wei ${ }^{6}$, Y. Zou ${ }^{7}$, X. Feng ${ }^{1}$, L. Sun ${ }^{1} .{ }^{1}$ Department of Rheumatology and Immunology, the Affiliated Drum Tower Hospital of Nanjing University Medical School, Nanjing; 22Department of Rheumatology, Huaian First People's Hospital, Huaian ${ }^{3}$ Department of Rheumatology, Xuzhou Central Hospital, Xuzhou;

Abstract AB0445 - Table 1

\begin{tabular}{|c|c|c|c|c|c|c|c|c|c|c|}
\hline Hydroxychloroquine use & Class II & Class III & Class IV & Class V & $\begin{array}{l}\text { Hill Biopsy } \\
\text { Index }\end{array}$ & $\begin{array}{l}\text { Activity } \\
\text { Index }\end{array}$ & $\begin{array}{l}\text { Chronicity } \\
\text { Index }\end{array}$ & $\begin{array}{l}\text { End of FUP eGFR } \\
(\mathrm{ml} / \mathrm{min})\end{array}$ & $\begin{array}{l}\text { End of FUP serum } \\
\text { creatinine }(\mathrm{mg} / \mathrm{dl})\end{array}$ & $\begin{array}{l}\text { End of FUP proteinuria } \\
(\mathrm{g} / 24 \mathrm{~h})\end{array}$ \\
\hline Yes $(n=18)$ & $39 \%$ & $28 \%$ & $28 \%$ & $22 \%$ & $0,86(0,2-1,8)$ & $1(0-4,25)$ & $0,75(0-3,25)$ & $99,8(81,9-112,1)$ & $0,74(0,7-0,8)$ & $0,3(0,1-0,6)$ \\
\hline No $(n=12)$ & $8 \%$ & $17 \%$ & $58 \%$ & $33 \%$ & $1,52(0,98-2,01)$ & $7,25(1,38-9)$ & $2,25(0,13-5,25)$ & $98,6(56,4-120,3)$ & $0,78(0,7-1,3)$ & $0,75(0,15-2,6)$ \\
\hline$p$-value & 0,09 & NS & NS & NS & 0,03 & 0,07 & NS & NS & NS & 0,09 \\
\hline
\end{tabular}

